\title{
COUNTRY-OF-ORIGIN EFFECTS ON PRODUCT EVALUATIONS
}

\author{
WARREN J. BILKEY* \\ University of Wisconsin-Madison \\ ERIK NES* * \\ Gustav A. Ring, A.S.
}

\begin{abstract}
This article reviews the literature regarding the effect of country of origin on buyer evaluations of products. The issue is important for countries (especially resource-poor, developing countries) that need to increase manufactured exports and for firms that source products in countries different from where sold. Marketing inferences are drawn, and implications for future research are developed.
\end{abstract}

The international product life-cycle model incorporates only supply-side variables - such as, product competition, complexity of production, and relative production costs. Demand-side variables - such as, the effect of country sourcing on the demand for that product - are not considered. If the latter is important, the usefulness of the international product life-cycle model as a guide for product sourcing would be limited.

The significance of the location of production on demand can be approached as an information cue question. That is, from an information theoretic perspective, products may be conceived as consisting of an array of information cues, both intrinsic (taste, design, fit) and extrinsic (price, brand name, warranties). Each cue provides customers with a basis for evaluating the product. The study of informational cues has generated much basic research in marketing - including the impact of various cues on perceived risk, on perceived quality, and on purchasing behavior, and also on how cues are processed by customers. Much applied research by industry centers around the impacts of intrinsic and extrinsic cues regarding products.

The informational cue on which this article focuses is the country of origin of a product. Usually this is communicated by the phrase, "Made in (name of country)." Both empirical observations and experiments indicate that country of origin has a considerable influence on the quality perceptions of a product. One such example is the West German firm, Battenfeld Mashinenfabriken, which established production of its standard injection molding machines to the U.S. to serve both the North American and Latin American markets (Business Week, 1979). Although Battenfeld Mashinenfabriken has a Brazilian subsidiary with access to that country's lush export subsidies, the company's sales director stated that many customers "won't buy a machine made in Brazil. U.S.-made products, by contrast, find ready acceptance abroad." Another example encountered several years ago by one of the authors was a Puerto Rican shoe manufacturer who shipped his entire production to New York City and back and advertised those shoes as being from New York. Experience had convinced him that Puerto Ricans would buy his shoes more readily when they were perceived as made in New York rather than in Puerto Rico. Similar anecdotes are widespread in developing countries. Experimental research on the country-of-origin informational cue is reviewed next.

\footnotetext{
*Warren Bilkey is Professor of International Business at the University of Wisconsin-Madison. * Erik Nes received his Ph.D. in international Business from the University of Wisconsin and currently directs the international affairs of the Norwegian firm, Gustav A. Ring, A.S.
} 
RESEARCH FINDINGS General

Within MDCs

MDCs vs. LDCs
Considerable effort has been expended in ascertaining whether country of origin affects product evaluations. Characteristics of major research on the subject are outlined in the appendix; all of those studies indicate that country of origin does indeed affect product evaluations. This holds for products in general [Anderson and Cunningham 1972; Bannister and Saunders 1978; Darling undated; Dornoff, Tankersley, and White 1974; Gaedeke 1973; Krishnakumar 1974; Lillis and Narayana 1974; Nagashima 1970, 1977; Reierson 1966; Wang 1978; White 1979]; for classes of products [Dornoff, Tankersley, and White 1974; Gaedeke 1973; Krishnakumar 1974; Nagashima 1970, 1977; Reierson 1966]; for specific types of products [Gaedeke 1973; Hampton 1977; Krishnakumar 1974; Reierson 1966; Schooler 1965, 1971; Schooler and Sunoo 1969; Schooler and Wildt 1968; Tongberg 1972; White and Cundiff 1978]; and for specific brands [Gaedeke 1973; Kincaid 1970; Yaprak 1978]. It holds whether the product source countries are various MDCs (more developed countries), MDCs vs. LDCs (less developed countries), and within LDCs. Stereotyping has been found among U.S., British, Finnish, Swedish, Japanese, Guatemalan, Turkish, Indian, and Taiwanese respondents. It may influence both industrial purchasing decisions and consumer purchasing decisions.

Several studies found that products made in different, more developed countries are not all evaluated equally [Bannister and Saunders 1978; Darling undated; Dornoff, Tankersley, and White 1974; Hampton 1977; Kincaid 1970; Lillis and Narayana 1974; Nagashima 1970, 1977; Krishnakumar 1974; Reierson 1966; Schooler 1971; Schooler and Wildt 1968; Tongberg 1972; Wang 1978; White 1979; White and Cundiff 1978; Yaprak 1978]. Attitudes may change over time - the studies indicate an improvement in the Japanese image and a relative deterioration of the U.S. image [Dornoff, Tankersley, and White 1974; Nagashima 1977]. There is a tendency for consumers to evaluate their own country's products relatively more favorably than do foreigners. This is quite clear in Nagashima [1970] and Lillis and Narayana [1974] concerning the U.S. and Japan and is indicated in Bannister and Saunders [1978] for England and in Darling [undated] for Finland. Studies reporting U.S. consumer attitudes toward U.S. products usually placed U.S. products in first place, while foreign studies, particularly European, have rated U.S. products comparatively lower [Bannister and Saunders 1978; Bruskin, Int. 1962; Darling undated; Nagashima 1977; Opinion Research Corp. 1959; Readers Digest Corp. 1963].

Several studies found a hierarchy of biases. These include a seemingly positive relationship between product evaluations and degree of economic development [Krishnakumar 1974; Schooler 1971; Tongberg 1972; Wang 1978; Hampton 1977]. Other apparent explanatory variables are the source country's culture and political climate [Wang 1978] and perceived similarity with the source country's belief system [Tongberg 1972]. The latter variable showed a strong correlation with economic development; the two former variables also appear to correlate highly with economic development. The bias seems to be stronger against Eastern European nations than their degree of economic development should indicate [Bannister and Saunders 1978; Darling undated; Schooler 1971; Wang 1978]. Specifically, Wang [1978] found that U.S. consumers perceived the USSR's degree of economic development to be higher than it actually is and still gave very low evaluations to its products. This may be explained by Wang's "political climate" variable.

Respondents from certain countries have different attitudes regarding products from a given country than do respondents from other countries. Krishnakumar [1974] found that Indian students rated British products higher than did Taiwanese students and attributed the difference to former colonial ties. Yaprak [1978], Nagashima [1970], and Lillis and Narayana [1974] all found differences among respondents' attitudes in two countries regarding products from a third country. 
Gaedeke [1973] found that U.S. made products were perceived as being of higher quality than products made in various LDCs, and that specific brands might be evaluated higher or lower when LDC country of origin was revealed as compared with no country-of-origin information being given.

Schooler and Wildt [1968] demonstrated that for many consumers the effect of product evaluation bias can be offset by price concessions. As the price of the domestic good was increased relative to the foreign good, more consumers switched to the foreign good against which they had evidenced bias.

Schooler [1965] found that Guatemalan students gave lower evaluations to products from El Salvador and Costa Rica than to domestic and Mexican products and that these were related to a general negative attitude toward people from those countries. Yaprak [1978] tested purchase intentions among U.S. and Turkish business executives for specific brands made in West Germany, Japan, and Italy and found a significant correlation between purchase intentions and various source country attributes.

Krishnakumar [1974] used a sample of students from Taiwan and India studying in the U.S. He found that the students discriminated against their own products in favor of MDC products. Students from Taiwan, with a higher GNP per capita, discriminated less than did Indian students. The Taiwanese students rated their own food and fashion products as better than MDC products. This indicates that MDC products which are very different from domestic products may not be good substitutes. Some very limited evidence indicates that the hierarchy of bias, referred to earlier, also is operational among LDCs.

Schooler [1971] and Tongberg [1972] found that older persons tended to evaluate foreign products more highly than did younger persons. Whereas Wang [1978] found no such effect. Schooler [1971] and Dornoff et al. [1974] found that females rated foreign products more highly than did males, but Dornoff et al. [1974] could not confirm this for products made in more developed countries. Schooler [1971], Anderson and Cunningham [1972], Dornoff et al. [1974], and Wang [1978] found that persons with more education tended to rate foreign products more highly than did persons with limited education, but Tongberg [1972] found no such relationship. Wang [1978] found that non-whites tended to rate products from Latin America and Africa higher than did whites; Schooler [1971] found that non-whites evaluated products from Nigeria, Latin America, and India higher than did whites while whites rated products from the U.S. and North America more highly than did non-whites. Wang [1978] found that higher income persons tended to have a more favorable acceptance of foreign products in general than did lower income persons.

Anderson and Cunningham [1972] found an inverse relationship between level of dogmatism and preference for foreign products. Tongberg [1972] found no relation between a person's degree of dogmatism and his or her attitudes toward products from 13 specific countries when the type of country was disregarded, but among high dogmatics there was a favorable attitude toward products made in culturally similar countries. Both Anderson and Cunningham [1972] and Wang [1978] found an inverse relation between conservatism and attitude toward foreign products in general. Dogmatism and to a certain extent conservatism also would seem to be especially relevant for communist-made products, but research did not focus on that issue. Anderson and Cunningham [1972] found an inverse relation between status concern and preference for foreign products.
Bias within LDCs

Demographic Variables

Personality Variables 
Promotion and Country of Origin Effect

Perceived Risk and Country of Origin Bias

Industrial Purchasing
Etzel and Walker [1974] studied the degree of congruence between general national product stereotypes and attitudes toward specific products. They found a significant difference between general country attitudes and specific product attitudes by country of source. They concluded that it might be misleading to base advertising on general national product attitudes, because specific product attitudes are more relevant. Such differences between general national product attitudes and more specific product attitudes have been demonstrated or indicated also by Gaedeke [1973], Reierson [1966], Nagashima [1970, 1977], and Krishnakumar [1974]. This implies (and has been demonstrated in several of the studies) that attitudes toward products from a country vary by product. What determines which products are evaluated the highest and the lowest has not been studied but it merits investigation.

Schleifer and Dunn [1968] found that U.S. students' attitudes toward advertised products were more favorable when the advertisements were associated with Americans than when associated with Egyptians. The Egyptian advertisements used Egyptian models and copy with an English translation attached. (Such an experimental situation may have been unrealistic.) They also found that attitude regarding a product increased when a favorable national reference group rating was given in the form of a consumer test. Their results led to the speculative conclusion that testimonial advertising may be particularly effective in international advertising.

Reierson [1967] found that exposure to communication and promotion improved attitudes toward Italian products, but not Japanese products. He concluded that advertising may be effective if prejudice is not too strong. (Note that the attitude toward Japanese products at that time was lower than now.) This may be explained in terms of Sherif and Hovland's [1965] social judgment theory, with promotion for the most negatively perceived country falling in the area of rejection. Of several promotional devices tested, Reierson [1967] found the greatest effect from a prestigious retailer's window display. A positive relationship between perceived quality and association with a prestigious retailer also was demonstrated in price research reviewed by Olson [1977].

Hampton [1977] tested perceived risk for American products made in the U.S. compared with the same products made by U.S. companies abroad. He found a general increase in perceived risk for products made abroad. Some specific products showed lower risk when made abroad. Most of these cases were products made in other MDCs; one was made in Brazil and one in Hong Kong. None of these cases involved products made in poorer LDCs. The Brazilian case was for freeze dried coffee and the Hong Kong case was for electronic calculators. The Hong Kong case may indicate a pattern for a country that has earned a reputation for this type of product. The Brazilian case may indicate a pattern where the country is a renowned exporter of the particular raw material and its reputation carried over to the processed product from the same raw material. If this hypothesis is correct, certain LDCs may have a special advantage in exporting manufactured goods based on their present reputation as exporters of raw materials. This could be the case for freeze dried coffee from Brazil, Colombia, and Tanzania; cocoa from Nigeria; sugar products from Cuba; and rubber products from Malaysia.

Hampton's [1977] findings also indicate that there may be a hierarchy of perceived risk having an inverse relationship with economic development. No interaction was found between countries and products. Hence, a low-risk product made in the U.S. might be perceived as a high-risk product when made in a high-risk country.

Significant differences in U.S. purchasing manager's perceptions of various attributes of products from five MDCs were found by White [1979]. White and Cundiff 
[1978] found significant differences in perceived quality based on country of origin. No effect on perceived quality was found by manipulating price within 10 percent. No interaction between price and country of origin was identified. These two studies support the suggested hierarchy of bias with regard to economic development referred to earlier, although the sample of countries analyzed was very limited.

Haakansson and Wootz [1975] tested the relative importance of supplier characteristics (location, size) and bid characteristics (price, quality, delivery time) under different perceived risk conditions, using a sample of Swedish purchasing managers as respondents. Location (Sweden-England/West Germany-and Francel Italy), explained 50 percent of the variance and was the most important of the supplier characteristics. The researchers found the rank-ordering to be Sweden England/West Germany - France/Italy and labeled the discriminating variable as "distance." However, the findings may also be explained in terms of the consumer attitude studies reported earlier, which indicated a relative preference for domestic products among the MDCs. The higher rank of the combination England/West Germany than the combination France/ltaly is not contradicted by the consumer studies.

Price was found to be the most important bid characteristic in low-risk situations, and quality and location in high-risk situations. Fitting an LDC supplier of industrial goods into a low-risk purchasing situation may maximize his price advantage and minimize his location disadvantage.

All of the studies referred to earlier found that country of origin did influence product evaluations. It is tempting to try to infer the magnitude of this relationship. Unfortunately, that would not be warranted because of the following methodological limitations. First, most of the studies involved only a single cue; that is, country of origin was the only information on which respondents based their evaluations. A single cue study is bound to yield a significant cue effect that might or might not exist in the real world. Second, in much of that research the respondents were given only verbal references to products, rather than shown a tangible product. One cannot be sure what respondents have in mind when such evaluations are given. For example, if a respondent evaluates the quality of an intangible sweater made in Sweden more highly than an intangible sweater made in Morocco, it might be that he has different sweaters in mind with regard to raw materials, sweater thickness, price, and other attributes. This is an important limitation when "made in ___ is the only informational cue given. Schooler [1971] found that product evaluations might differ according to whether a tangible or an intangible product is used. A related type of confounding (unintentional manipulation of two or more variables within a single independent variable) may be found where the source country is given as "a foreign country" or as a geographical area. Attitude toward foreign products could depend on whether the respondent has West Germany or Afganistan in mind when hearing "foreign country," and the attitude toward products "made in Asia" might depend upon whether Japan or Indonesia is the frame of reference. A third limitation has to do with the general validity and reliability problems often encountered in consumer research. Differing versions of the semantic differential scale were used in several of the studies. Only Kincaid [1970] used the adjectives developed by Osgood [1952]; unfortunately, the validity and reliability demonstrated by Osgood's work cannot be imputed to other scales. Demand effects are possible in most of the studies (that is, respondents guess the purpose of the study, which affects their responses); usually there is no report of respondent debriefing; and validity and reliability assessments of the measurements used tend to be inadequate or nonexistent. The importance of measurement validity was demonstrated by Tongberg [1972]. He obtained very low 
coefficients of determination between a general preference ranking of products from various nations and multi-attribute scale measures that ranged from $r^{2}=.020$ to $r^{2}=.187$ for various product classes.

REMAINING ISSUES

Within the limits of the methodologies employed, all of the studies reviewed indicate that country of origin does indeed influence buyer perceptions of the products involved. The issue of how much influence that cue provides is not yet decided. Several studies, referred to in Olson and Jacoby [1972], found that intrinsic cues (the product's characteristics) had a greater effect on quality judgments than did extrinsic cues (considerations associated with the product). This suggests that the country-of-origin (an extrinsic) cue might have only a limited influence on product quality perceptions.

A second issue is whether, and to what extent, other cues - such as, a well-known brand name, a product guarantee, or a prestigious retailer-can compensate for a negative country-of-origin cue. Andrews and Valenzi [1971] found that the effects of price on quality evaluations of products tended to vary inversely with brand name familiarity. Might similar relationships exist between the country-oforigin cue and other extrinsic cues? If products sourced in LDCs are perceived to be more risky than the same products sourced in an industrialized country [as suggested by Hampton 1977], then the literature on consumer risk relievers and the effects of risk on information processing [reviewed in Ross 1974] becomes relevant. For example, industrial purchasing of LDC products might involve price stability risks, uncertainty regarding delivery times, uncertainty regarding quality, and so on. Risk relievers might include guarantees by third parties, tests by independent laboratories, and warehousing within importing countries, among others. This issue is important for multinational companies considering sourcing in LDCs and for retailers importing from such countries under private labels.

A third issue is the determinants of country-of-origin biases. Is this a function of source country considerations (such as degree of economic development or political climate), of consuming country considerations (such as import experiences, nationalism, or cultural affinity with the source of country), or of something else? Knowledge about this issue would provide a basis for determining whether country-of-origin biases are deep-seated or superficial and whether it would be more effective to combat them or to compensate for them.

A fourth issue is possible intercorrelations between the country-of-origin cue and other cues. Because manufactured imports from LDCs tend to be lower priced than comparable products made in the U.S. or imported from industrialized countries [Cline 1979], any cue effects of price on the perceived quality of products would tend to intercorrelate with their country of origin. This would have a reinforcing effect on negative biases regarding products sourced in LDCs.

IMPLICATIONS Country-of-origin cues that are biased against products sourced in LDCs logically would rotate the international product life-cycle function counterclockwise; that is, raise the right end of the curve. This would result from whatever additional expenditures (or lower prices) are needed to compensate for the country-of-origin cue. The amount of rotation presumably would vary directly with the behavioral importance of this cue, which has yet to be estimated precisely.

A counterclockwise rotation of the international product life-cycle function logically would likely reduce investments in and exports from LDCs relative to what would occur without the adverse country-of-origin cue. Both effects would slow down the economic development of affected LDCs at the very time their populations are growing rapidly.

Both the theoretical and practical consequences of the country-of-origin cue are 
so great that additional research on the subject would seem to be urgently needed. For example, how important is the cue? How can it be reduced or compensated? Such research must involve more than single cue surveys and experiments; multicue studies conforming as nearly as possible to real life purchasing conditions are needed.

Anderson, W. T., and Cunningham, William H. "Gauging Foreign Product Promotion." Journal of Advertising Research, February 1972, pp. 29-34.

Andrews, I. R., and Valenzi, E. R. "Combining Price, Brand Name and Store Cues to Form an Impression of Product Quality." Proceedings of the 79th Annual Convention of the American Psychological Association, 1971.

Bannister, J. P., and Saunders, J. A. "UK Consumers' Attitudes Towards Imports: The Measurement of National Stereotype Image." European Journal of Marketing 12 (1978), pp. 562570.

Bruskin International. Europe: A World of Profit for Markets. New York, 1962.

Business Week. "Exports: German Lessons for U.S. Industry." 7 May 1979, p. 50.

Cline, William R. "Imports and Consumer Prices: A Survey Analysis." Study prepared for the American Retail Federation and the National Merchants Association, 1979.

Darling, John R. "An Analysis of Consumer Attitudes Towards the Products and Marketing Practices of U.S. Manufacturers." Unpublished and undated working paper, Wichita State University, Wichita, Kansas.

Dornoff, Ronald J.; Tankersley, Clint B.; and White, Gregory P. "Consumers' Perceptions of Imports." Akron Business and Economic Review 5 (Summer 1974), pp. 26-29.

Etzel, Michael J., and Walker, Bruce J. "Advertising Strategy for Foreign Products."; Journal of Advertising Research 14 (June 1974), pp. 41-44.

Gaedeke, Ralph. "Consumer Attitudes Toward Products 'Made In' Developing Countries." Journal of Retailing 49 (Summer 1973), pp. 13-24.

Haakansson, Haakan, and Wootz, Bjorn. "Supplier Selection in an International Environment - An Experimental Study." Journal of Marketing Research 12 (February 1975), pp. 4651.

Hampton, Gerald M. "Perceived Risk in Buying Products Made Abroad By American Firms." Baylor Business Studies, October 1977, pp. 53-64.

Howard, John A. Consumer Behavior: Application of Theory. New York: McGraw-Hill Inc., 1977.

Johanson, J., and Vahlne, J. "The Internationalization Process of the Firm - A Model of Knowledge Development and Increasing Foreign Market Commitments." Journal of International Business Studies, Spring/Summer 1977, pp. 23-32.

Keesing, D. B. "World Trade and Output of Manufactures: Structural Trends and Developing Countries' Exports." World Bank Staff Working Paper No. 316, 1979.

Kincaid, William M. Jr. "A Study of the Perception of Selected Brands of Products as Foreign or American and Attitudes Toward Such Brands." Ph.D. dissertation, The University of Texas at Austin, 1970.

Krishnakumar, Parameswar. "An Exploratory Study of the Influence of Country of Origin on the Product Images of Persons from Selected Countries." Ph.D. dissertation, The University of Florida, 1974.

Lillis, Charles M., and Narayana, Chem L. "Analysis of 'Made In' Product Images - An Exploratory Study." Journal of International Business Studies, Spring 1974, pp. 119-127.

Morgan, Theodore, Economic Development. New York: Harper \& Row, 1975.

Nagashima, Akira. "A Comparison of Japanese and U.S. Attitudes Toward Foreign Products." Journal of Marketing 34 (January 1970), pp. 68-74.

“A Comparative 'Made In' Product Image Survey Among Japanese Businessmen." Journal of Marketing, July 1977, pp. 95-100.

Olson, Jerry C. "Price as an Informational Cue: Effects on Product Evaluations." In Consumer and Industrial Buying Behavior, edited by A. G. Woodside, J. N. Sheth, and P. D. Bennett. North-Holland 1977.

, and Jacoby, Jacob. "Cue Utilization in the Quality Perception Process." In Proceedings of the Third Annual Conference of the Association for Consumer Research, edited by M. Venkatesan. 1972.

Opinion Research Corporation. "American Firms and Brands in the European Common Market." Public Opinion Index for Industry. Princeton, 1959. 
Osgood, C. E. "The Nature and Measurement of Meaning." Psychological Bulletin (May, 1952).

Readers Digest Corporation. European Common Market and Britain. New York, 1963.

Reierson, Curtis. "Are Foreign Products Seen as National Stereotypes?" Journal of Retailing, Fall 1966, pp. 33-40.

"Attitude Changes toward Foreign Products." Journal of Marketing Research (November 1967), pp. 385-387.

Ross, Ivan. "Perceived Risk and Consumer Behavior: A Critical Review." In Advances in Consumer Research, Vol. II, edited by M. J. Schlinger. Urbana, IL: Association for Consumer Research, 1974.

Rothschild, Michael L. "Advertising Strategies for High and Low Involvement Situations." In Research Plays for High Stakes, edited by John Maloney. 1979.

Schleifer, Stephen, and Watson, Dunn, S. "Relative Effectiveness of Advertisements of Foreign and Domestic Origin." Journal of Marketing Research 5 (August 1968), pp. 296-299.

Schooler, Robert D. "Product Bias in the Central American Common Market." Journal of Marketing Research 2 (November 1965), pp. 394-397.

"Bias Phenomena Attendant to the Marketing of Foreign Goods in the U.S." Journal of International Business Studies, Spring 1971, pp. 71-80.

Schooler, Robert D. and Sunoo, Don H. "Consumer Perceptions of International Products: Regional vs. National Labeling." Social Science Quarterly, March 1969, pp. 886-890.

APPENDIX Research Dealing with

Country-of-Origin Cue Effects on Product Evaluations.
General Studies

Schooler 1965

Reierson 1966

Schooler and Wildt 1968

Schooler and Sunoo 1969

Nagashima 1970

Kincaid 1970

Schooler 1971

Tongberg 1972

Anderson and Cunningham 1972

Gaedeke 1973

Lillis and Narayana 1974 students

students

students

students

businessmen

students

adults

adults + students

adults

students

adults
Products

Consuming countries 
Schooler, Robert D., and Wildt, Albert R. "Elasticity of Product Bias." Journal of Marketing Research 5 (February 1968), pp. 78-81.

Sherif, Muzafer, and Hovland, Carl I. "Social Judgment; Assimilation and Contrast Effects in Communication and Attitude Change." New Haven: Yale University Press, 1965.

Tongberg, R. C. "An Empirical Study of Relationships Between Dogmatism and Consumer Attitudes Toward Foreign Products." Ph.D. disseration, The Pennsylvania State University, 1972.

Wang, Chih-Kang. "The Effect of Foreign Economic, Political and Cultural Environment on Consumers' Willingness to Buy Foreign Products." Ph.D. dissertation, Texas A \& M University, 1978.

White, Phillip D. "Attitudes of U.S. Purchasing Managers Toward Industrial Products Manufactured in Selected European Nations." Journal of International Business Studies, Spring/ Summer 1979, pp. 81-90. , and Cundiff, Edward W. "Assessing the Quality of Industrial Products." Journal of Marketing, January 1978, pp. 80-86.

Yaprak, Attila. "Formulating a Multinational Marketing Strategy: A Deductive Cross-National Consumer Behavior Model." Ph.D. dissertation, Georgia State University, College of Business Administration, 1978.

\begin{tabular}{|c|c|c|c|c|}
\hline $\begin{array}{l}\text { Source } \\
\text { countries }\end{array}$ & $\begin{array}{l}\text { Ta) } \\
\text { or I }\end{array}$ & $\begin{array}{l}E^{\text {b) }} \\
\text { or } S\end{array}$ & $\begin{array}{l}\left.\mathrm{S}^{c}\right) \\
\text { or } \mathrm{N}\end{array}$ & $\begin{array}{l}\text { Measure of } \\
\text { evaluation }\end{array}$ \\
\hline
\end{tabular}

\begin{tabular}{|c|c|c|c|c|}
\hline $\begin{array}{l}\text { Guatemala, El Salvador, Costa Rica, } \\
\text { Mexico }\end{array}$ & $\mathrm{T}$ & $E$ & M & Attitude \\
\hline 10 industrialized nations & 1 & $S$ & $\mathrm{~S}$ & $\begin{array}{l}\text { Quality } \\
\text { assessment }\end{array}$ \\
\hline U.S. and Japan & $\mathrm{T}$ & $E$ & M & $\begin{array}{l}\text { Purchase } \\
\text { preference }\end{array}$ \\
\hline $\begin{array}{l}\text { Asia, Africa, South America, and } \\
\text { Western Europe }\end{array}$ & $\mathrm{T}$ & $E$ & M & Attitude \\
\hline $\begin{array}{l}\text { U.S., West Germany, England, Japan, } \\
\text { and other industrialized nations }\end{array}$ & 1 & $S$ & $\mathrm{~S}$ & Attitude \\
\hline Netherlands, Italy, West Germany, & 1 & $E$ & M & Attitude \\
\hline
\end{tabular}

U.S., West Germany, India, Czechoslovakia, Chile, Nigeria, +6 areas

13 nations at various stages of economic development

Foreign products in general

$\begin{array}{cccc}\text { T and } & \text { E } & \text { M } & \text { Attitude } \\ \text { I } & \text { S } & \text { S } & \text { Attitude } \\ \text { I } & \text { S } & \text { S } & \text { Attitude }\end{array}$

$\begin{array}{llllll}\text { U.S. and various developing nations } & \text { I } & \text { S } & \text { S } & \text { Attitude } \\ \begin{array}{l}\text { England, France, West Germany, } \\ \text { Japan, and U.S. }\end{array} & 1 & \text { S } & \text { S } & \text { Attitude }\end{array}$




\begin{tabular}{|c|c|c|c|}
\hline Reference & Subjects & Products & $\begin{array}{l}\text { Consuming } \\
\text { countries }\end{array}$ \\
\hline Krishnakumar 1974 & students & $\begin{array}{l}\text { General + mechanical } \\
\text { and electronic products, } \\
\text { food, fashion, cars, } \\
\text { TV sets, soft drinks, } \\
\text { and dress shirts }\end{array}$ & $\begin{array}{l}\text { U.S., India, } \\
\text { Taiwan }\end{array}$ \\
\hline Dornoff et al. 1974 & adults & $\begin{array}{l}\text { General + food, fashion, } \\
\text { electronic and } \\
\text { mechanical products }\end{array}$ & U.S. \\
\hline Nagashima 1977 & businessmen & General +6 classes & Japan \\
\hline Hampton 1977 & $\begin{array}{l}\text { adults }+ \\
\text { students }\end{array}$ & $\begin{array}{l}27 \text { products in } 3 \text { classes } \\
\text { of perceived risk }\end{array}$ & U.S. \\
\hline $\begin{array}{l}\text { Bannister and } \\
\text { Saunders } 1978\end{array}$ & adults & Durable goods in general & England \\
\hline Yaprak 1978 & businessmen & $\begin{array}{l}\text { Cars, cameras, and } \\
\text { calculators. One brand } \\
\text { per country per product }\end{array}$ & Turkey, U.S. \\
\hline Wang 1978 & adults & General & U.S. \\
\hline Darling & $\begin{array}{l}\text { students }+ \\
\text { professionals }\end{array}$ & General & Finland \\
\hline \multicolumn{4}{|c|}{ Promotion and country of origin effects } \\
\hline Reierson 1967 & students & General + specific & U.S. \\
\hline $\begin{array}{l}\text { Schleifer and } \\
\text { Watson Dunn } \\
1968\end{array}$ & students & $\begin{array}{l}4 \text { ads for everyday } \\
\text { consumer products }\end{array}$ & U.S. \\
\hline $\begin{array}{l}\text { Etzel and } \\
\quad \text { Walker } 1974\end{array}$ & adults & $\begin{array}{l}\text { General + cars, cameras, } \\
\text { and toys }\end{array}$ & U.S. \\
\hline \multicolumn{4}{|c|}{ Studies in industrial purchasing } \\
\hline $\begin{array}{l}\text { Haakanson and } \\
\text { Wootz } 1975\end{array}$ & $\begin{array}{l}\text { purchasing } \\
\text { managers }\end{array}$ & $\begin{array}{l}\text { Standard and special } \\
\text { screw, paint, and pressing } \\
\text { tool }\end{array}$ & Sweden \\
\hline $\begin{array}{l}\text { White and } \\
\text { Cundiff } 1978\end{array}$ & $\begin{array}{l}\text { industrial } \\
\text { buyers }\end{array}$ & $\begin{array}{l}\text { Lift truck, dictation } \\
\text { system, and machine tool }\end{array}$ & U.S. \\
\hline White 1979 & $\begin{array}{l}\text { purchasing } \\
\text { managers }\end{array}$ & $\begin{array}{l}\text { Industrial products in } \\
\text { general }\end{array}$ & U.S. \\
\hline
\end{tabular}

a) = Tangible (T) or intangible (l) products being evaluated.

b) $=$ Experimental design (E) or attitude survey (S).

c) = Single cue study (S) or multiple cue study (M). 


\begin{tabular}{|c|c|c|}
\hline $\begin{array}{l}\text { Source } \\
\text { countries }\end{array}$ & $\begin{array}{l}\mathrm{Ta} \\
\text { or }\end{array}$ & $\begin{array}{c}E^{(b)} \\
\text { or } S\end{array}$ \\
\hline
\end{tabular}

U.S., West Germany, England, India, $\quad$ I $\quad S \quad$ S Attitude Taiwan, and Japan

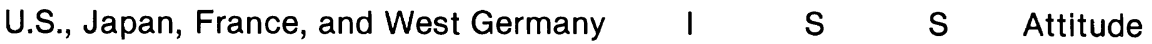

U.S., West Germany, England, Japan, $\quad$ I $\quad$ S $\quad$ S Attitude and other industrialized nations

9 nations in 3 classes

S S Perceived

France, Italy, Japan, England, U.S., $\quad$ I $\quad$ S $\quad$ S Attitude

USSR, and West Germany

West Germany, Japan, Italy

S S Purchase

intention

36 countries

S S Willingness

England, Finland, France,

West Germany, U.S., Japan, Sweden, to buy and USSR

Italy, Japan

U.S., Egypt

S S Attitude

U.S., West Germany, and Japan

I S S Attitude

Sweden, England/West Germany, and

France/ltaly (pairwise)

E S Attitude

E S Attitude

U.S., West Germany, Japan, and Brazil I $\quad$ E $\quad M \quad$ Attitude

U.S., West Germany, France, Italy, and I $S$ S Attitude

England 